NOTE

\title{
Grazing of Calanus helgolandicus on Dinophysis norvegica during bloom conditions in the North Sea: evidence from investigations of faecal pellets
}

\author{
C. Wexels Riser ${ }^{1, *}$, S. Jansen ${ }^{2}$, U. Bathmann ${ }^{2}$, P. Wassmann ${ }^{1}$ \\ ${ }^{1}$ Norwegian College of Fishery Science, University of Tromsø, 9037 Tromsø, Norway \\ ${ }^{2}$ Alfred Wegener Institute for Polar and Marine Research, Am Handelshafen 12, 27570 Bremerhaven, Germany
}

\begin{abstract}
Toxic dinoflagellate blooms are a common phenomenon in the North Sea, but the fate of the toxins in the food web is largely unknown. Herbivorous copepods may play a key role in the transport of toxins through the food web, but it is still uncertain to what extent toxic algae are grazed. The present experiment was carried out during an autumn bloom of Dinophysis norvegica in the North Sea, to study whether Calanus helgolandicus feed on Dinophysis spp. under natural conditions. The experiment showed that $C$. helgolandicus fed very efficiently on $D$. norvegica at high

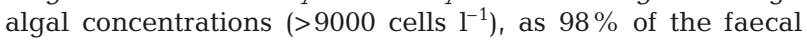
pellets (FP) produced contained Dinophysis spp. cells (up to 32 cells $\mathrm{FP}^{-1}$ ). Therefore, $C$. helgolandicus feeds on $D$. norvegica under natural conditions, and its FP may be an important vehicle transferring toxins within the pelagic and to the benthic community.
\end{abstract}

KEY WORDS: Zooplankton · Dinophysis spp. · Calanus helgolandicus · Grazing · Faecal pellet

Resale or republication not permitted without written consent of the publisher

In marine ecosystems the transfer of toxins to higher trophic levels such as fishes, birds and whales has been suggested to occur via tintinnids (Maneiro et al. 2000), clams (Prepas et al. 1997) and copepods (Teegarden \& Cembella 1996, Tester et al. 2000). Herbivorous zooplankton may produce toxin-containing faecal pellets (FP) after ingesting toxic algae; these can be consumed by other zooplankton in the water column or they can sink out of the water column (Maneiro et al. 2000). Since one of the largest loss factors of phytoplankton is due to zooplankton grazing, it is important to understand how harmful algae species affect zooplankton grazing. Avoidance of toxic dinoflagellates may enhance bloom development. Toxic phytoplankton cells are thought to be less attractive to zoo- plankton grazers, and toxic cells should be selectively avoided by zooplankton when feeding on mixtures of different prey species (Fiedler 1982, Teegarden et al. 2001).

Due to their high sinking rates (Smayda 1969, Komar et al. 1981) copepod FP often comprise a significant fraction of the vertical carbon export out of the euphotic zone (Wassmann et al. 1999, Wexels Riser et al. 2002). The membrane-enclosed FP that all copepods produce can contain recognisable remains of their food. Therefore, the FP production approach was chosen to study whether or not Calanus helgolandicus feeds on toxic dinoflagellates of the genus Dinophysis. The ecology and ecophysiology of Dinophysis spp. remains poorly understood, mostly because it has not been possible to culture these species. Field experiments are therefore important for increasing the knowledge of the interactions between Dinophysis spp. and their potential predators.

Materials and methods. The present work was carried out during a Lagrangian experiment aboard RV 'Heincke' in the North Sea in August 2001 (cruise HE152). A patch with enhanced dinoflagellate concentrations was marked with a surface float equipped with a GPS radio transmitter. Copepods for the experiment were collected from $30 \mathrm{~m}$ to the surface at $56^{\circ} 18.57^{\prime} \mathrm{N}$, $6^{\circ} 38.91^{\prime} \mathrm{E}$ by vertical net tows with a WP2 zooplankton net (180 $\mu \mathrm{m}$ mesh size). Adult Calanus helgolandicus females were placed in 5 experimental bottles $(1180 \mathrm{ml}$ volume, containing 5 individuals each), and 1 control bottle without copepods was run simultaneously. The control bottle was used to correct for initial FP numbers in the incubation water. Incubation water was collected from the chlorophyll maximum (17 m depth) using Niskin bottles, and pre-screened through a 
$200 \mu \mathrm{m}$ mesh to remove larger zooplankton. The experimental bottles were carefully closed to prevent any air bubbles and placed onto a plankton wheel in an on-deck flow-through incubator to maintain uniform cell distribution at in situ temperature (17 \pm $0.5^{\circ} \mathrm{C}$ ). The experiment was carried out in dim light for $24 \mathrm{~h}$. At the end of the incubation experiment, the copepods were removed and the contents from the bottles were carefully sieved through a $20 \mu \mathrm{m}$ Nitex mesh and preserved with buffered formaldehyde $(2 \%$ final concentration). All FP were enumerated using an inverted microscope with phase contrast and ocular micrometer (Zeiss IM 35). The length and width (or diameter) of the pellets was measured and the FP volume (FPV) calculated using appropriate stereometrical configurations according to Edler (1979). A volumetric carbon conversion factor of $69.4 \mu \mathrm{g} \mathrm{C} \mathrm{mm}{ }^{-3}$ (Riebesell et al. 1995) was applied to estimate FP carbon (FPC). Photographs of FP were taken with a Nikon 500 digital camera at 100 to $150 \times$ magnification. In addition, samples were prepared for scanning electron microscopy (SEM). These samples were filtered on $0.2 \mu \mathrm{m}$ polycarbonate membrane filters, rinsed with deionised water to remove salt and formaldehyde and then airdried. Filters were placed on SEM stubs and sputtered with gold/palladium for $3 \mathrm{~min}$ (25 mA, $5 \mathrm{~nm}$ ). SEM photographs were taken at $400 \times$ magnification.

Results and discussion. The total cell concentration of dinoflagellates (Dinophysis spp. and Ceratium spp.) ranged between 1000 and 18000 cells $l^{-1}$ during the Lagrangian experiment and $D$. norvegica was the predominant dinoflagellate species during the drift experiment. Dinophysis spp. produced Dinophysis Toxin 1 (DTX1), but no okadaic acid (OA) (Catherine Legrand

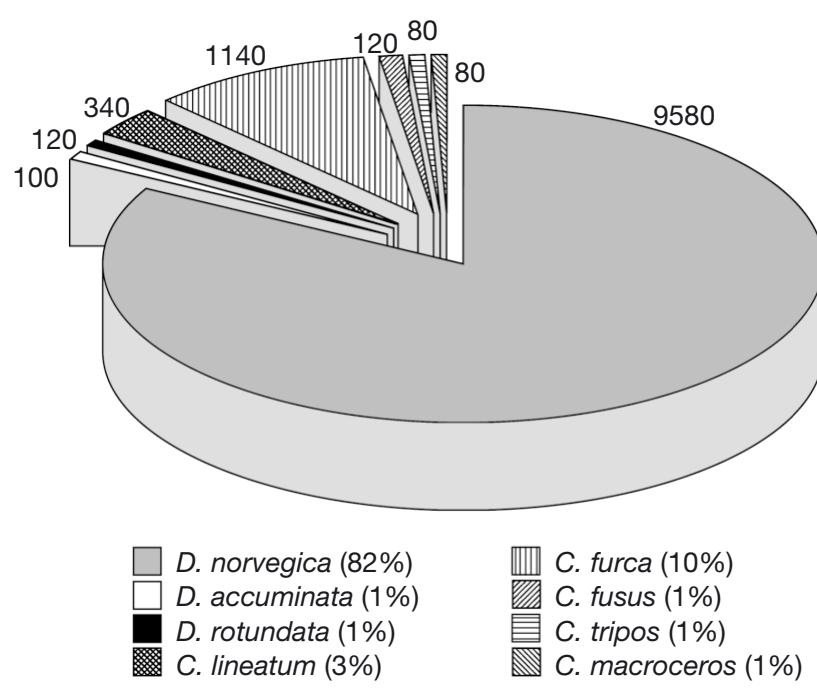

Fig. 1. Dinoflagellate species composition in the incubation water (cells $~^{-1}$ )
Table 1. Calanus helgolandicus. Faecal pellet (FP) production rate, volume and carbon production (means $\pm 95 \%$ confidence intervals)

Production rate $\left(\mathrm{FP}\right.$ ind. $\left.{ }^{-1} \mathrm{~d}^{-1}\right)$ :

$23.6 \pm 1.6$

FP volume produced $\left(\mathrm{mm}^{3}\right.$ ind..$\left.^{-1} \mathrm{~d}^{-1}\right)$ :

FP carbon produced ( $\mu \mathrm{g} \mathrm{C}$ ind.$^{-1} \mathrm{~d}^{-1}$ ):

$0.026 \pm 0.010$

$1.82 \pm 0.75$

Table 2. Length, diameter and volume (means $\pm \mathrm{SE}$ ) of Calanus helgolandicus faecal pellets (FP) produced by adult females. Only intact FP are included $(n=466)$; these were $86.8 \%$ of all FP $(n=537)$
FP length $(\mu \mathrm{m})$ :

FP diameter $(\mu \mathrm{m})$ :

FP volume $\left(\times 10^{4} \mu^{3}\right)$ :
$374 \pm 5.0$
$65.9 \pm 0.4$
$137 \pm 3.29$

pers. comm.). Dinophysis spp. was the principal dinoflagellate genus in the incubation water and $D$. norvegica was by far the most numerous species, with 9580 cells $1^{-1}$, or $82 \%$ of the number of cells (Figs. 1 \& 2a). C. furca was the most numerous species of the genus Ceratium, comprising $10 \%$ of the cells, or 1140 cells $\mathrm{l}^{-1}$.

The FP production rate of Calanus helgolandicus was 24 FP female ${ }^{-1} \mathrm{~d}^{-1}$ (Table 1), which was relatively low compared to other studies (e.g. Corner et al. 1972). Table 2 shows the average FP length, diameter and volume. The average volume of the FP was $137 \times$ $10^{4} \mu^{3}$, similar to that reported by Harris (1994). No 'ghost pellets' were observed; $87 \%$ of the FP were intact and only $13 \%$ showed signs of fragmentation (Table 2). No Ceratium spp. cells or remains of Ceratium spp. were detected within the FP. According to Teegarden et al. (2001), Ceratium spp. are unsuitable food for copepods and avoided by grazers; however, from investigations of FP content only, it cannot be concluded that $C$. helgolandicus did not feed on Ceratium spp. Nevertheless, Ceratium spp. probably did not make up a large fraction of the diet, and the cells must have been destroyed before or during egestion.

Photographs of the FP suggest that Calanus helgolandicus ingested but did not digest (no empty cells observed) Dinophysis norvegica cells (Fig. 2b-f). A total of $98 \%$ of the FP produced during the experiment contained $D$. norvegica. The number of $D$. norvegica cells within one FP ranged from 0 to 32, with an average of $19 \pm 2.5 \mathrm{SE}$. This represents an ingestion rate of 400 to 500 Dinophysis spp. cells ind.-1 $\mathrm{d}^{-1}$. Earlier experiments indicate that Temora longicornis is able to ingest Dinophysis spp. cells, but the ingestion rate was too low to affect a bloom or the fate of diarrhetic shellfish poisoning (DSP) toxins in the food web (Maneiro et al. 2000, 2002). 

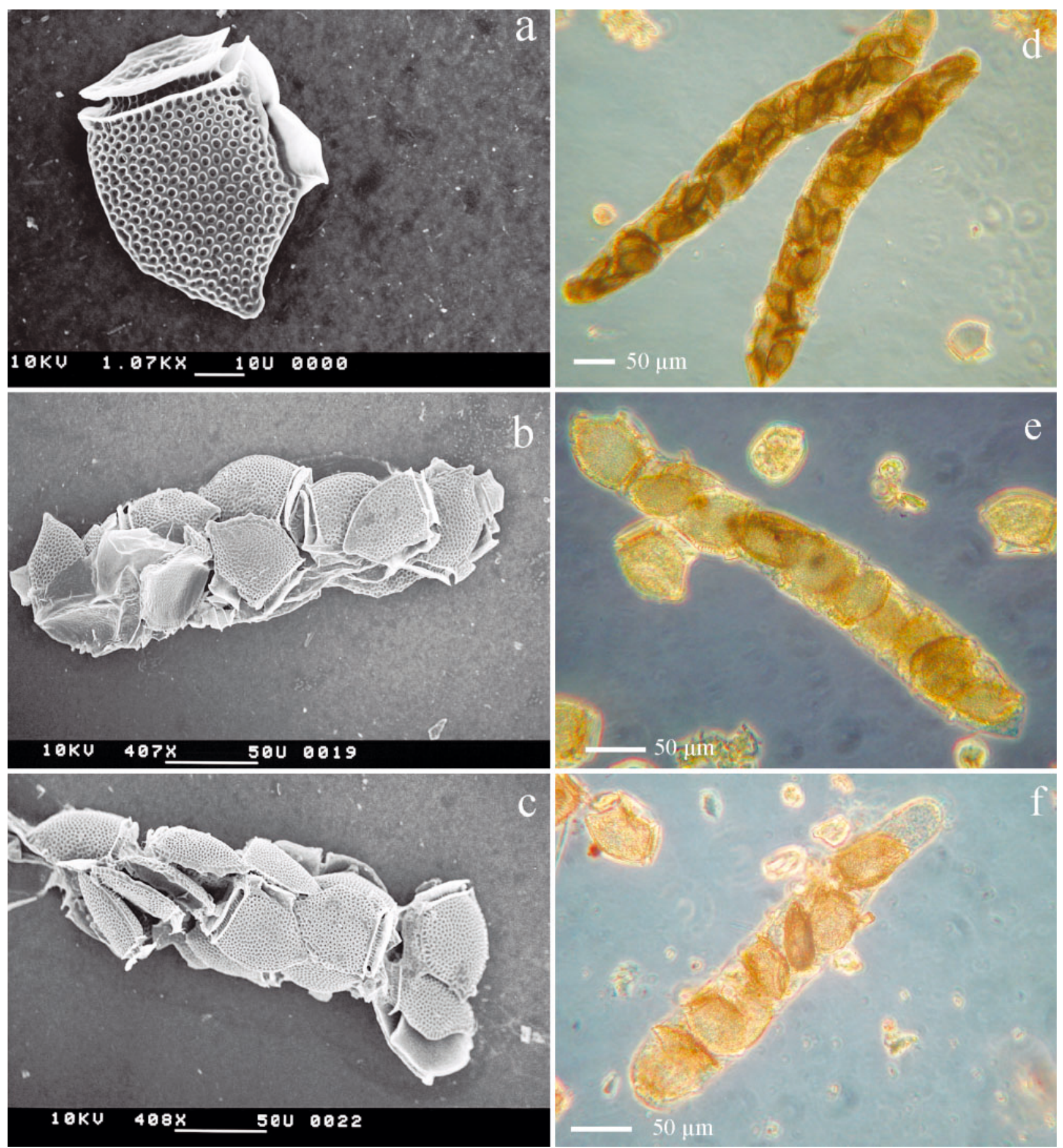

Fig. 2. Scanning electron micrographs (SEM) of (a) Dinophysis norvegica, (b,c) Calanus helgolandicus faecal pellet containing $D$. norvegica; (d-f) light micrographs of $C$. helgolandicus faecal pellets containing $D$. norvegica

Our experiment shows that Calanus helgolandicus feeds efficiently on Dinophysis norvegica under natural conditions. This may play an important role in the transport of DSP toxins through the food web and in the fate of Dinophysis spp. blooms, particularly in periods when Dinophysis experience sub-optimal growth conditions. Due to the very high concentration of Dino- physis and relatively low abundance of $C$. helgolandicus ( 2800 adults $\mathrm{m}^{-2}$ at 0 to $30 \mathrm{~m}$ depth) their grazing could not have had a great impact on the fate of the bloom or the transport of DSP toxins through the food web at the time of the experiment. The experiment also shows that studies of phytoplankton remains in FP may provide important information on toxic blooms. 
Acknowledgements. We thank the captain and crew of RV 'Heincke' of the Alfred Wegener Institute for Polar and Marine Research for their support. Particular thanks are due to C. Legrand, A. Skovgaard and U. Tillmann for spending days at the microscope to provide the 'BIOHAB group' with on-board cell counts. We also thank C. Svensen for improving the manuscript. This work was supported by the European Commission (Research Directorate General Environment Programme-Marine Ecosystems) through the BIOHAB project 'Biological control of harmful algal blooms in European coastal waters: role of eutrophication' (contract EVK3-CT99-00015). The BIOHAB project is part of the EC EUROHAB cluster.

\section{LITERATURE CITED}

Corner EDS, Head RN, Kilvington CC (1972) On the nutrition and metabolism of zooplankton. VIII. The grazing of Biddulphia cells by Calanus helgolandicus. J Mar Biol Assoc UK 52:847-861

Edler L (ed) (1979) Recommendations for marine biological studies in the Baltic Sea-phytoplankton and chlorophyll. Baltic Marine Biologists, Vol 5, Gotab

Fiedler PC (1982) Zooplankton avoidance and reduced grazing responses to Gymnodinium splendens (Dinophyceae). Limnol Oceanogr 27:961-965

Harris RP (1994) Zooplankton grazing on the coccolithophore Emiliana huxleyi and its role in inorganic carbon flux. Mar Biol 119:431-439

Komar PD, Morse AP, Small LF, Fowler SW (1981) An analysis of sinking rates of natural copepod and euphausiid fecal pellets. Limnol Oceanogr 26:172-180

Maneiro I, Frangópulos M, Guisande $C$, Fernàndez $M$, Reguera B, Riveiro I (2000) Zooplankton as a potential vector of diarrhetic shellfish poisoning toxins through the food web. Mar Ecol Prog Ser 201:155-163

Editorial responsibility: Otto Kinne (Editor), Oldendorf/Luhe, Germany
Maneiro I, Guisande C, Frangópulos M, Riveiro I (2002) Importance of copepod faecal pellets to the fate of DSP toxins produced by Dinophysis spp. Harmful Algae 1: 333-341

Prepas EE, Kotak BG, Campbell LM, Evans JC, Hrudey SE, Holmes CFB (1997) Accumulation and elimination of cyanobacterial hepatoxins by the freshwater clam Anodonta grandis simpsoniana. Can J Fish Aquat Sci 54:41-46

Riebesell U, Reigstad M, Wassmann P, Passow U, Noji TT (1995) On the trophic fate of Phaeocystis pouchetii. VI. Significance of Phaeocystis-derived mucus for vertical flux. Neth J Sea Res 33:193-203

Smayda TJ (1969) Some measurements of the sinking rate of faecal pellets. Limnol Oceanogr 14:621-625

Teegarden GJ, Cembella AD (1996) Grazing of toxic dinoflagellates, Alexandrium spp., by adult copepods of coastal Maine: implications for the fate of paralytic shellfish toxins in marine food webs. J Exp Mar Biol Ecol 196:145-176

Teegarden GJ, Campbell RG, Durbin EG (2001) Zooplankton feeding behavior and particle selection in natural plankton assemblages containing toxic Alexandrium spp. Mar Ecol Prog Ser 218:213-226

Tester PA, Turner JT, Shea D (2000) Vectorial transport of toxins from the dinoflagellate Gymnodinium breve through copepods to fish. J Plankton Res 22:47-61

Wassmann P, Hansen L, Andreassen IJ, Wexels Riser C, Urban-Rich J (1999) Distribution and sedimentation of faecal pellets on the Nordvestbanken shelf, northern Norway, in 1994. Sarsia 84:239-252

Wexels Riser C, Wassmann P, Olli K, Pasternak A, Arashkevich E (2002) Seasonal variation in production, retention and export of zooplankton faecal pellets in the marginal ice zone and central Barents Sea. J Mar Res 38:175-188

Submitted: February 14, 2003; Accepted: April 17, 2003 Proofs received from author(s): May 28, 2003 